trace, doubtless due to tremor of the mirror, and, though not so well marked, yet quite similar in character to the gaps described in a previous letter (NATURE, No. I4IO, November 5, I896); at 5.32 p.m. another abrupt movement to the north, and a similar one at $\mathrm{Ih} .20 \mathrm{~m}$. after midnight. The three abrupt movements have been compared with the mean of two measures of the sensitiveness of the instrument, and show tilts in the mirror frame of $\mathbf{I} \cdot 6, \mathbf{I} \cdot \mathrm{I}$, and $\mathrm{I} \cdot 3$ seconds of arc respectively. In each case the mirror returned to the normal position slowly after a period of from 2 to 4 hours.

On the other date given by Prof. Milne-February I3-there is only a slight trace of irregularity in the curve, consisting of a bend towards the north at $8 \mathrm{~h} .2 \mathrm{~m}$. a.m., the mirror returning to its original position three hours later.

On dates more recent than those to which Prof. Milne calls attention, several disturbances have been recorded here. Of these the most strongly marked are : an abrupt north movement on February 16 at 8 p.m., and another on the 17 th at $3 \mathrm{a} . \mathrm{m}$. On the r8th there is a similar movement to the south at 6.15 a.m., followed by two smaller oscillations in the opposite direction, the three covering a period of $\mathrm{I}_{2}^{\frac{1}{2}}$ hours. On February I9 there are two well-marked gaps, precisely similar in character to those described in the letter above referred to.

Royal Observatory, Edinburgh, March 2.
I892 Captain V. Bóttego obtained no less than eighteen specimens of that most singular rodent, Heterocephaluts glaber, in one day, at the Wells of Herrer, near Archeisa, in North Somaliland. Sixteen specimens, well preserved in alcohol, were forwarded by him to Marquis Giacomo Doria, and have been distributed to various museums through the learned Director of the Museo Civico of Genoa. In his book (" Il Giuba esplorato," pp. 38-4I, Roma, I895) Captain Bóttego figures the Heterocephalus, and also one of their colonies of singular conical mole-hills.

Florence, February 24.

Henry H. Giglioli.

\section{THE CAUCASUS ${ }^{1}$}

ITTLE though the methods and spirit of sport have in common with those of science, each subject is greatly indebted to the other. Our knowledge of the habits of big game is mainly due to hunters; and for the first great advances in mountain cartography and in the study of high mountain regions, we are indebted to climbers. In the early days of the Alpine Club some of its members, at the suggestion of John Ball, placed instruments on summits that were accessible only to

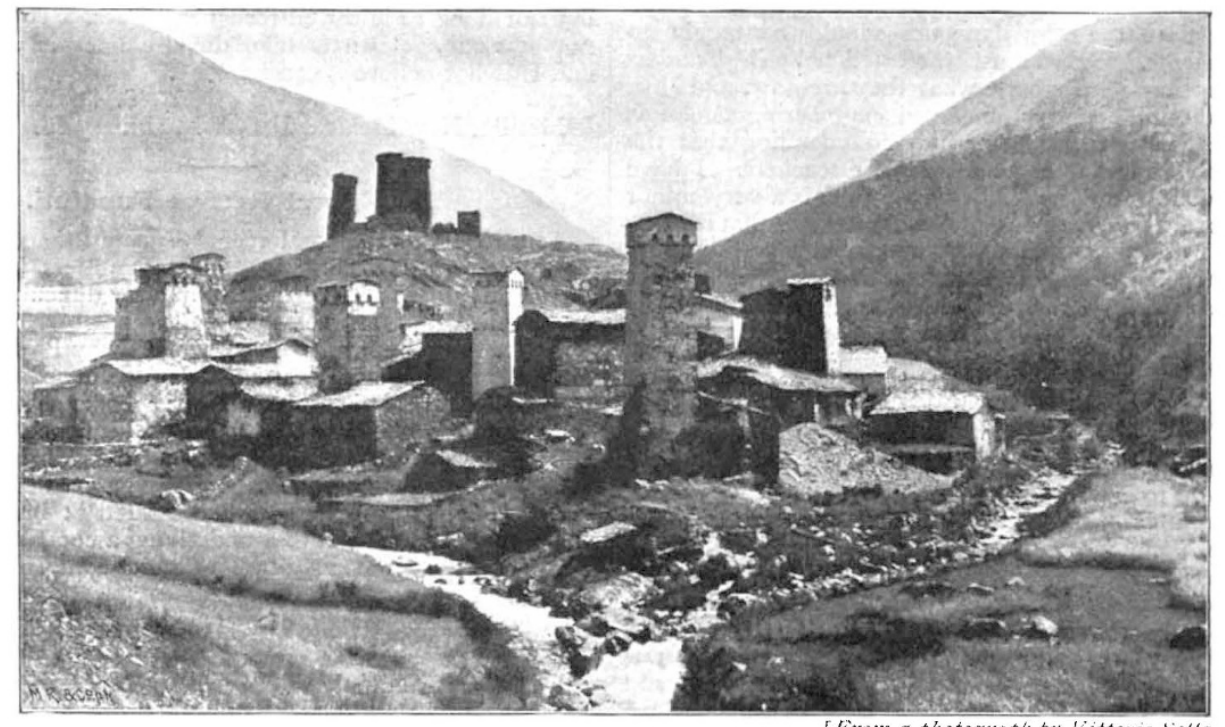

Fic. 1.-Ushku!.

[From a photograph by Vittorio Sella.

The Origin of Manna.

The note in NAture, p. 349 , concerning the "manna," reminds me of a passage in Daniele Bartoli's "Asia."

Speaking of the island of Ormuz - which is described as one of the places in the world worst supplied in even commonest necessities of life, and scarcely having any water-the historian tells us that "not even thorns and briars could grow on its barren soil ; no animals or birds (sic) are seen there all the year round, but every morning a dew falls which congeals into grains, has a very sweet taste, and is called 'manna."

Now, tamarisks affect sandy soils or brackish shores; and as $T$. mannifera grows in Arabia, it may be that the exudations from the plants were blown from Oman, on the eastern shore of Arabia, across the Persian Gulf; or, perhaps, from the nearer coast of Persia. This would seem to confirm the belief that manna is the product of the tamarisk, and not of a lichen.

Tooting College, S.W., February 26. $\quad$ B. Tiмotнy.

"Heterocephalus glaber" in North Somaliland.

IN reference to the note given in NATURE (vol. lv. p. 301) on the mammals collected in North-east Africa by Dr. Donaldson Smith, it may interest some of your readers to learn that in October NO. I 428 , VOL. 55$]$ trained mountaineers, and thus obtained meteorological records much wanted at that time. Subsequently, another group of members of the Alpine Club turned their attention to the Caucasus, where their explorations resulted in the first accurate knowledge of its lofty summits and its great snow-fields and glaciers. Of the Alpine climbers who have taken part in this work, Mr. Douglas Freshfield was one of the earliest, was the best qualified as a geographer, and has been by far the most persistent. His "Central Caucasus and Bashan" (1869), which has taken place as an Alpine classic, helped to rouse the first interest in England regarding the former mountains ; and now, after thirty years' further work has been done, he has collected the principal results into a monograph, which is unquestionably the best illustrated book in the literature of mountaineering.

Mr. Freshfield begins with a chapter on the "Dis-

I "The Exploration of the Caucasus." By Douglas W. Freshfield. With illustrations by Vittorio Sella. Imp. 8vo. 2 vols. Pp. xxiii +278 ; pp. $\mathrm{x}+295$; with 3 maps and 76 full-page iflustrations, and 2 mountain panoramas. (London : Edward Amold, 1896.) 